\title{
VARIASI GENETIK IKAN BERONANG (Siganus guttatus) ASAL PERAIRAN BARRU, LAMPUNG, DAN SORONG MENGGUNAKAN PENANDA RAPD (Random Amplified Polymorfism DNA)
}

\author{
Samuel Lante, Andi Tenriulo, dan Neltje Nobertine Palinggi \\ Balai Penelitian dan Pengembangan Budidaya Air Payau \\ Jl. Makmur Dg. Sitakka No. 129, Maros 90512, Sulawesi Selatan \\ E-mail: samuellante98@yahoo.co.id
}

(Naskah diterima: 20 Mei 2011 ; Disetujui publikasi: 30 April 2012)

\begin{abstract}
ABSTRAK
Evaluasi variasi genetik ikan beronang, Siganus guttatus telah dilakukan untuk mengetahui keragaman genetik di alam dalam upaya mendukung pembenihan secara terkontrol. Sampel ikan beronang diperoleh dari 3 (tiga) lokasi perairan di Indonesia yaitu: Barru (Sulawesi Selatan), Lampung (Sumatera), dan Sorong (Papua Barat) masingmasing sebanyak 10 ekor. Analisis variasi genetik dilakukan dengan metode random amplified polimorfism DNA (RAPD), menggunakan 5 (lima) primer (OPA3, OPA6, OPA7, OPA16, dan OPA20). Variasi genetik dianalisis menggunakan software TFPGA (Tools For Population Genetic Analysis). Kedekatan hubungan kekerabatan ditampilkan dalam dendrogram. Hasil Penelitian menunjukkan bahwa ikan beronang populasi Lampung mempunyai variasi genetik tertinggi yaitu $75,86 \%$, dan terendah adalah populasi Barru $(62,07 \%)$. Indeks similaritas ikan beronang tertinggi $(0,9583)$ diperoleh antara populasi Barru dengan Sorong, dan indeks similaritas terendah $(0,7996)$ antara populasi Sorong dengan Lampung. Berdasarkan jarak genetik ikan beronang pada penelitian ini diperoleh dua kelompok utama yaitu (1) Barru dan Sorong, dan (2) Lampung.
\end{abstract}

KATA KUNCl: variasi genetik, ikan beronang, indeks similaritas, jarak genetik, penanda RAPD

ABSTRACT: Genetic variation of rabbitfish, Siganus guttatus populations in Barru, Lampung, and Sorong using marker Random Amplified polymorphism DNA (RAPD). By: Samuel Lante, Andi Tenriulo, and Neltje Nobertine Palinggi

Evaluation of genetic variabilities of wild rabbitfish, Siganus guttatus was conducted to know genetic variation as basic knowledge in order to develop sustainable breeding. Samples of rabbitfish was collected from three locations in Indonesian waters i.e.; Barru (South Sulawesi), Lampung (Sumatra), and Sorong (West Papua). Number of samples from each location were 10 fishes. RAPD analysis was applied using five primers (OPA3, OPA6, OPA7, OPA 16, and OPA20). Genetic variability was analyzed by using software Tools for Population Genetic Analysis (TFPGA). Genetic distance was shown in dendrogram. The results of this study indicated that rabbitfish from Lampung waters had the highest genetic variability (75.86\%), while the lowest (62.07\%) was obtained from Barru waters. The highest index similarity of rabbitfish (0.9583) was obtained between population of Barru and Sorong, and the lowest (0.7996) between Sorong and Lampung. Genetic distance of rabbitfish in this research can be divided into two groups are (1) Barru and Sorong and (2) Lampung.

KEYWORDS: genetic variation, rabbitfish, index similarity, genetic distances, RAPD marker 


\section{PENDAHULUAN}

Ikan beronang, S. guttatus merupakan salah satu spesies ikan yang mempunyai nilai ekonomis tinggi, yang sampai saat ini diperoleh dari hasil tangkapan di alam. Penangkapan ikan secara kontinu dapat menyebabkan besaran populasi di alam berkurang. Salah satu indikator tekanan populasi di alam didukung data statistik Dinas Kelautan dan Perikanan Provinsi Sulawesi Selatan bahwa total produksi ikan beronang tahun 2006 adalah 955,2 ton menurun menjadi 121,4 ton pada tahun 2007 (Anonim, 2008). Upaya untuk menanggulangi penurunan produksi ikan ini adalah melakukan budidaya. Kegiatan budidaya ikan beronang telah dilakukan di Selat Dompak Kepulauan Riau (Lamidi et al., 1996) dan Sulawesi Selatan (Palinggi et al., 2009; Lante \& Usman, 2010), namun kegiatannya masih dalam skala kecil.

Kendala utama budidaya ikan beronang adalah kurang tersedianya benih, karena benih yang bersumber dari alam bersifat musiman, tidak seragam, dan belum dikelola dengan baik. Upaya pembenihan perlu segera dilakukan untuk mengurangi ketergantungan di alam, pemenuhan kebutuhan benih untuk budidaya, dan kelestarian dalam rangka pemulihan populasi di alam (Lante, 2010). Upaya pembenihan ikan beronang telah dilakukan oleh Balai Penelitian dan Pengembangan Budidaya Air Payau Maros, mulai dari teknik pematangan gonad sampai pemijahan telah berhasil dilakukan dengan cara manipulasi hormonal (Lante et al., 2008), namun sintasan larva masih rendah (Lante \& Palinggi, 2010). Sintasan larva ikan beronang yang rendah tersebut sangat dipengaruhi oleh kualitas induk yang digunakan selama pembenihan. Salah satu aspek yang perlu dilakukan untuk mengetahui kualitas induk adalah mengevaluasi sumber keragaman genetik ikan di alam untuk penyediaan mutu genetik ikan bagi pembenihan yang merupakan informasi penting bagi suatu populasi (Ferguson et al., 1995).

Salah satu pendekatan untuk mengetahui variasi genetik ikan adalah melalui marker genetik menggunakan analisis Random Amplified Polimorphic DNA (RAPD). Analisis RAPD merupakan suatu aplikasi standar dari polymorphic Chain Reaction (PCR) yang digunakan untuk mendeteksi perbedaan polimorfik DNA yang ada antara spesies atau antar individu. Analisis keragaman genetik populasi pada beberapa ikan dengan meng- gunakan penanda RAPD telah dilakukan yaitu pada ikan terbang (Fahri, 2001), ikan napoleon (Moria et al., 2006); ikan Channa punctatus (Nagarajan et al., 2006), ikan Rutilus rutilus (Keyvanshokooh \& Kalbassi, 2006); dan ikan common carp (Basavaraju et al., 2007). Berdasarkan hal di atas, maka penelitian ini dilakukan untuk mengetahui variasi genetik meliputi derajat polimofik, indeks similaritas, dan jarak genetik populasi ikan beronang di alam dari tiga lokasi perairan di Indonesia dengan menggunakan penanda Random Amplified Polymorphism DNA. Hasil analisis diharapkan untuk mendapatkan informasi yang berhubungan dengan sumber genetik induk ikan beronang dari beberapa perairan di Indonesia untuk mendukung penyediaan induk bagi pembenihan.

\section{BAHAN DAN METODE}

\section{Sampel Ikan Beronang}

Pada penelitian ini, sampel ikan beronang diperoleh dari hasil tangkapan di alam terdiri atas 3 (tiga) populasi daerah penangkapan yang berbeda (Gambar 1) yaitu: di perairan Barru (Sulawesi Selatan) dengan bobot $264,33 \pm 61,58 \mathrm{~g}$; Lampung (Sumatera) dengan bobot 286,33 $\pm 126,55 \mathrm{~g}$; dan Sorong (Papua Barat) dengan bobot 243,67 $\pm 102,12 \mathrm{~g}$; masingmasing sebanyak 10 ekor. Sebanyak $50 \mathrm{mg}$ jaringan otot/daging ikan diambil, kemudian diawetkan dengan menggunakan $250 \mu \mathrm{L}$ TNES urea buffer dalam tabung ependorf volume 1,5 $\mathrm{mL}$. Kumpulan tabung ependort berisi sampel selanjutnya dimasukkan ke dalam wadah untuk dibawa ke laboratorium dan disimpan dalam suhu ruangan sampai dilakukan ekstraksi DNA.

\section{Ekstraksi DNA}

Sampel otot/daging ikan dalam tabung ependorf 1,5 mL; kemudian dilisiskan dengan menambahkan $500 \mu \mathrm{L}$ larutan lysis, $40 \mu \mathrm{L} 10 \%$ SDS dan $40 \mu \mathrm{L}$ proteinase-K selanjutnya diinkubasi pada $55^{\circ} \mathrm{C}$ selama 1-3 jam. Penambahan RNase sebanyak 12,5 $\mu \mathrm{L}(20 \mathrm{mg} / \mathrm{mL}$ larutan) dan disimpan pada suhu kamar selama 15-30 menit. Setelah itu, ditambahkan larutan fenol : kloroform : isoamyl alkohol (PCl) dengan perbandingan 25:24:1 dan kemudian di-vortex perlahan sampai homogen. Selanjutnya sampel disimpan pada suhu kamar selama 10 menit, kemudian disentrifugasi dengan kecepatan $13.000 \mathrm{rpm}$ selama 8 menit. Supernatan sebanyak $750 \mu \mathrm{L}$ dipindahkan ke tabung 


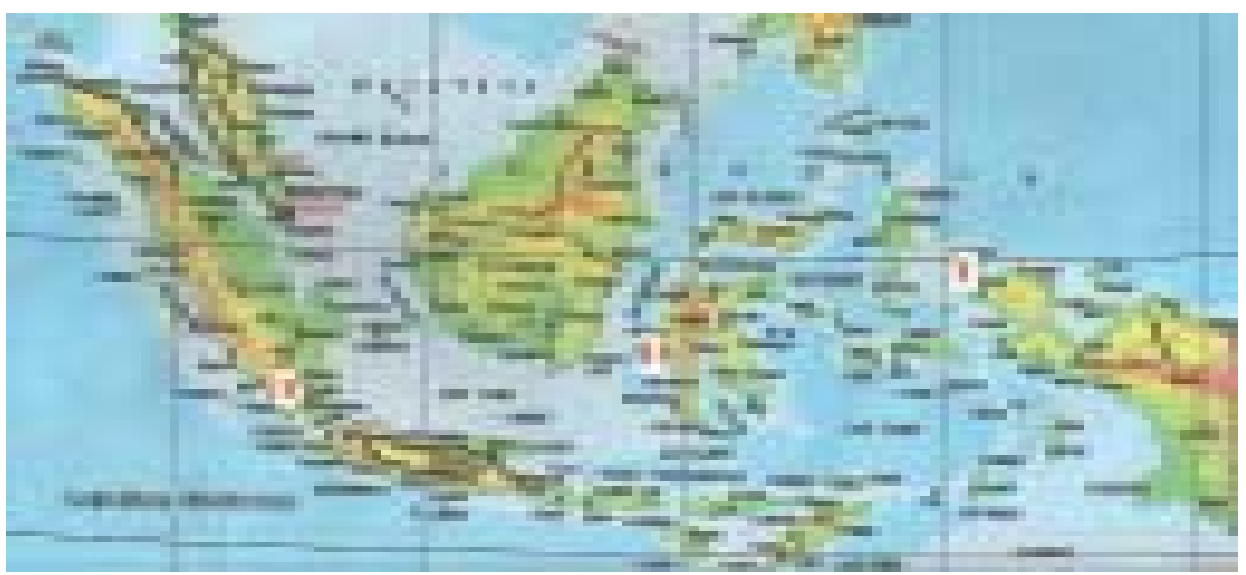

Gambar 1. Peta lokasi pengambilan sampel ikan beronang (S. guttatus) di perairan Barru, Lampung, dan Sorong ( $-=$ Lokasi sampling)

Figure 1. Map indicating locations of rabbitfish, S. guttatus sampling sites

ependorf baru $1,5 \mathrm{~mL}$ selanjutnya ditambahkan lagi fenol : kloroform : isoamyl alkohol (25:24:1) sebanyak $500 \mu \mathrm{L}$, setelah itu, sampel disimpan pada suhu kamar selama 10 menit kemudian disentrifugasi dengan kecepatan $13.000 \mathrm{rpm}$ selama 4 menit.

Tahap berikutnya sebanyak $600 \mu \mathrm{L}$ supernatan dipindahkan ke tabung ependorf baru, kemudian ditambahkan larutan campuran kloroform:isoamyl alkohol (24:1) dan disentrifugasi dengan kecepatan $13.000 \mathrm{rpm}$ selama 4 menit. Supernatan sebanyak $400 \mu \mathrm{L}$ ditambahkan larutan ethanol dingin sebanyak 2 bagian dari volume sampel kemudian disentrifugasi dengan kecepatan $6.000 \mathrm{rpm}$ selama 30 menit. Supernatan dibuang, kemudian pelet yang terbentuk ditambahkan ethanol $70 \%$ sebanyak $800 \mu \mathrm{L}$, kemudian digoyang dengan cara pembalikan beberapa saat selanjutnya disentrifugasi 2 kali yaitu dengan kecepatan 6.000 rpm selama 15 menit dan kecepatan $6.000 \mathrm{rpm}$ selama 6 menit. DNA yang mengendap terletak di dasar tube sebagai pelet berwarna putih. DNA dikering-anginkan pada suhu kamar selama lebih kurang 24 jam, kemudian DNA ditambahkan air suling atau TE buffer (10 mM Tris dan 1 mM EDTA, pH 8,0) sebanyak $100 \mu \mathrm{L}$ selanjutnya disimpan pada suhu $-20^{\circ} \mathrm{C}$ sebelum digunakan untuk langkah kerja berikutnya.

Untuk mengetahui keberhasilan ekstraksi DNA, campuran $7,5 \mu \mathrm{L}$ genom dan $2,5 \mu \mathrm{L}$ loading dye dielektroforesis dalam $0,8 \%(\mathrm{w} / \mathrm{v}) \mathrm{gel}$ agarose pada larutan Tris-Boric acid-EDTA (TBE) dengan tegangan 150 volt dan kuat arus 75 $\mathrm{mA}$ selama $1 \mathrm{jam}$. Gel direndam dalam 0,5 $\mathrm{gg} /$ $\mathrm{mL}$ larutan ethidium bromida agar pita genom dapat terlihat pada UV transilluminator dan selanjutnya didokumentasikan secara digital.

\section{Amplifikasi DNA dengan PCR}

Primer yang digunakan dalam RAPD ini adalah OPA3, OPA6, OPA7, OPA16, dan OPA20 dengan urutan basa tertera pada Tabel 1 . Amplifikasi DNA dengan menggunakan PuReTaq RTG-PCR beads (GE healthcare),

Tabel 1. Primer RAPD yang digunakan untuk analisis DNA

Table 1. RAPD primers that used to analyse $D N A$

\begin{tabular}{cc}
\hline $\begin{array}{c}\text { Jenis primer } \\
\text { Primer code }\end{array}$ & $\begin{array}{c}\text { Urut an basa 5'-3' } \\
\text { Basa sequence 5'-3' }\end{array}$ \\
\hline OPA3 & AGTCAGCCAC \\
OPA6 & GGTCCCTGAC \\
OPA7 & GAAACGGGTC \\
OPA16 & AGCCAGCGAA \\
OPA20 & GTTGCGATCC \\
\hline
\end{tabular}

Keterangan (Note):

OPA 3, 6, 7, 16, dan 20: Operon Teknologi Kit A Primer, $\mathrm{A}=$ Adenine; $\mathrm{C}=$ Cytosine; $\mathrm{G}=$ Guanine; dan $\mathrm{T}=$ Thymine (OPA 3, 6, 7, 16 and 20: Operon Technology Kit A primers, $A=$ Adenine; $C=$ Cytosine; $G=$ Guanine, and $T=$ Thymine 
selanjutnya dioperasikan dengan PCR Gene Amp System 2700 (Applied Biosystems) yang diprogram pada 45 siklus. Amplifikasi dilakukan menggunakan metode PCR dengan komposisi bahan: $1 \mu \mathrm{L}$ primer $(50 \mathrm{pmol} / \mu \mathrm{L}), 3$ $\mu \mathrm{L}$ DNA, dan $21 \mu \mathrm{L}$ water free RNAse sehingga mencapai total volume $25 \mu \mathrm{L}$. Komposisi larutan dalam volume $25 \mu \mathrm{L}$ dimasukkan dalam mesin PCR. Siklus PCR yang digunakan adalah satu siklus pre-denaturasi pada suhu $94^{\circ} \mathrm{C}$ selama 2 menit untuk aktivasi enzim taq polymerase, 45 siklus denaturasi pada suhu $94^{\circ} \mathrm{C}$ selama 30 detik, penempelan pada suhu $36^{\circ} \mathrm{C}$ selama 30 detik dan pemanjangan pada suhu $72^{\circ} \mathrm{C}$ selama 1,0 menit dan pada akhir PCR ditambahkan sintesis $2^{\circ} \mathrm{C}$ menit untuk menyakinkan semua hasil amplifikasi dalam bentuk untai ganda. Untuk mengetahui keberhasilan amplifikasi primer yang digunakan, campuran $3 \mu \mathrm{L}$ hasil PCR dengan 1,0 $\mu \mathrm{L}$ loading dye dielektroforesis dengan menggunakan gel agarosa 2,0\% dalam larutan TBE $1 \times$ selama 1,5 jam pada tegangan 150 volt. Gel direndam dalam larutan ethidium bromida pada konsentrasi $0,5 \mathrm{ng} / \mathrm{mL}$ agar pita DNA dapat terlihat pada UV transilluminator untuk keperluan dokumentasi menggunakan kamera.

\section{Analisis Data}

Pita DNA hasil amplifikasi dari 3 populasi menggunakan 5 (lima) primer diterjemahkan menjadi data biner dengan ketentuan pemberian nilai 1 (satu) untuk adanya pita dan pemberian nilai 2 (dua) untuk tidak adanya pita DNA. Data biner hasil skoring digunakan untuk menghitung jarak genetik, indeks similaritas, dan menyusun dendrogram melalui analisis kelompok. Derajat polimorfik (P0.95) dihitung dari jumlah lokus polimorfik/jumlah lokus total $\times 100 \%$. Variasi genetik dianalisis menggunakan TFPGA (Tools for Population Genetic Analysis) (Miller, 1997).

\section{HASIL DAN BAHASAN}

\section{Hasil Analisis RAPD}

Hasil amplifikasi DNA ikan beronang setiap primer disajikan pada Tabel 2. Primer OPA3 menghasilkan amplifikasi DNA sebanyak 13 pita dengan ukuran 200-1.050 bp, selanjutnya OPA6 dapat menghasilkan amplifikasi DNA lebih sedikit dari OPA3 yaitu 6 pita, tetapi memiliki ukuran pita lebih tinggi daripada primer OPA3 yaitu 200-1.250 bp. Sedangkan primer OPA7 dapat menghasilkan amplifikasi DNA 12 pita, namun memiliki ukuran pita yang lebih rendah dari primer OPA16 yaitu 2751.200 bp. OPA16 menghasilkan amplifikasi dengan jumlah pita 13 dan memiliki ukuran pita 175-1.250 bp. Primer OPA20 menghasilkan amplifikasi dengan jumlah pita (12) dan memiliki ukuran pita sama dengan primer OPA16 yakni 175-1.250 bp. Hasil pengamatan terhadap DNA ikan beronang menggunakan 5 primer menghasilkan total loci 174 pita yang terdiri atas 58 pita dari populasi Sorong, 58 pita populasi Barru, dan 58 pita populasi Lampung, di mana 121 pita di antaranya adalah polimorfik $(69,54 \%)$. Selanjutnya jumlah genotipe berkisar 5-9, demikian pula ukuran pita berkisar 175-1.250 bp (Tabel 3), dan elektroforesis hasil amplifikasi PCR DNA ikan beronang menggunakan primer OPA16 dan OPA20 (Gambar 2).

Hasil pengamatan memperlihatkan bahwa ketiga populasi ikan beronang memiliki jumlah dan ukuran pita yang sama, namun jumlah polimorfik dan jumlah genotipe yang berbeda.

Tabel 2. Jenis primer, jumlah dan panjang pita hasil amplifikasi DNA ikan beronang S. guttatus

Table 2. Fragment number and length of rabbitfish, S. guttatus DNA after amplified using various primers

\begin{tabular}{ccc}
\hline $\begin{array}{c}\text { Primer } \\
\text { Primers }\end{array}$ & $\begin{array}{c}\text { Jumlah pita } \\
\text { Number of fragments }\end{array}$ & $\begin{array}{c}\text { Panjang pita } \\
\text { Fragment length (bp) }\end{array}$ \\
\hline OPA3 & 13 & $200-1,050$ \\
OPA6 & 6 & $200-1,250$ \\
OPA7 & 12 & $275-1,200$ \\
OPA16 & 13 & $175-1,250$ \\
OPA20 & 12 & $175-1,250$ \\
\hline
\end{tabular}


Tabel 3. Jumlah pita, polimorfik, proporsi, jumlah genotip dan ukuran pita ikan beronang, $S$. guttatus

Table 3. Number of fragments, number of polymorphic, proportion of polimorphic, number of genotype and fragment sizes of DNA rabbitfish, S. guttatus

\begin{tabular}{lccccc}
\hline $\begin{array}{c}\text { Populasi } \\
\text { Populations }\end{array}$ & $\begin{array}{c}\text { Jumlah pita } \\
\text { Number of } \\
\text { fragments }\end{array}$ & $\begin{array}{c}\text { Jumlah } \\
\text { polimorfik } \\
\text { Number of } \\
\text { fragments } \\
\text { polimorphic }\end{array}$ & $\begin{array}{c}\text { Proporsi } \\
\text { polimorfik } \\
\text { Proportion of } \\
\text { polimorphic } \\
\text { (\%) }\end{array}$ & $\begin{array}{c}\text { Jumlah } \\
\text { genotipe } \\
\text { Number of } \\
\text { genotype }\end{array}$ & $\begin{array}{c}\text { Ukuran pita } \\
\text { fragments } \\
\text { (bp) }\end{array}$ \\
\hline Sorong & 58 & 41 & 70.69 & $6-9$ & $175-1,250$ \\
Barru & 58 & 36 & 62.07 & $5-7$ & $175-1,250$ \\
Lampung & 58 & 44 & 75.86 & $5-9$ & $175-1,250$ \\
\hline \multicolumn{1}{c}{ Total } & 174 & 121 & - & - & - \\
\hline
\end{tabular}
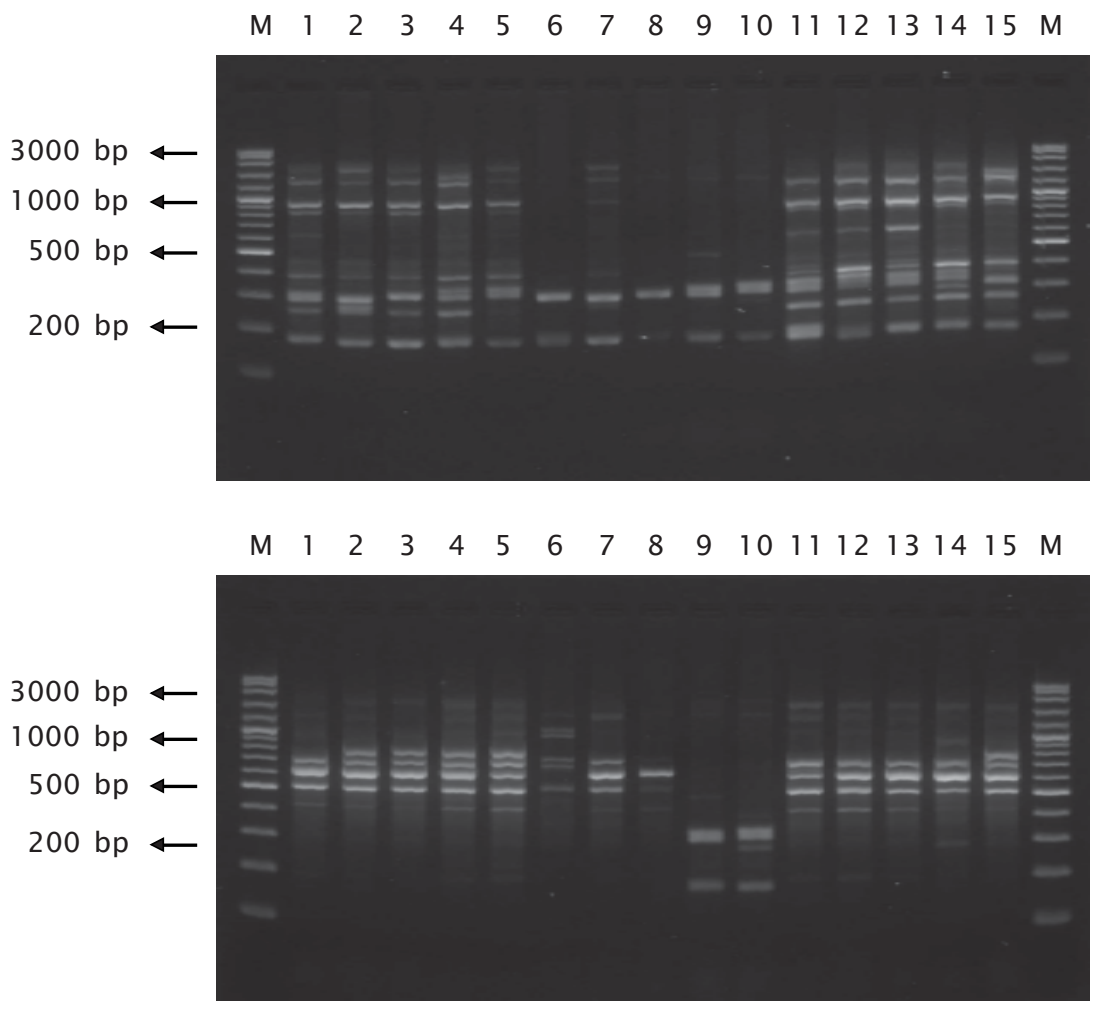

Keterangan (Remark):

$\mathrm{M}=$ Marker Hind III, angka 1-5 = sampel Barru, 6-10= sampel Lampung, 11-15= sampel Sorong (M= Marker Hind III, 1-5= Barru sample, 6-10= Lampung sample and $11-15$ = Sorong sample)

Gambar2. Profil pita DNA ikan beronang (S. guttatus) hasil amplifikasi menggunakan primer OPA16, dan OPA20

Figure 2. DNA fragment profile of rabbitfish amplified by using OPA 16, and OPA20 primer 
Hasil penelitian oleh beberapa peneliti yang telah menganalisis keragaman genetik ikan dengan penanda RAPD dan mendapatkan jumlah pita yang berbeda, antara lain: 1-10 pita pada ikan channel catfish, Ictalurus sp. (Liu \& Cordes, 1999); 1-9 pita pada ikan nila, Oreochromis niloticus (Arifin et al., 2007); dan 3-8 pita pada ikan Channa punctatus (Nagarajan et al., 2006). Dari hasil penelitian menunjukkan bahwa ukuran pita DNA ikan beronang berkisar 175-1.500 bp yang tidak berbeda antar ketiga populasi, namun berbeda dengan ukuran pita ikan beronang antara perairan Polman dan Malili sebesar 0,3768 (Lante, 2010). Ikan beronang populasi Barru, Lampung, dan Sorong menghasilkan kisaran genotipe berturut-turut 5-7, 5-9, dan 6-9. Hasil penelitian ini sesuai dengan hasil penelitian Asma (1999) yang menyatakan bahwa setiap varietas, spesies, dan populasi menghasilkan jumlah genotipe yang berbeda.

Proporsi polimorfik tertinggi diperoleh pada populasi Lampung $(75,86 \%)$, menyusul populasi Sorong $(70,69 \%)$ dan terendah pada populasi Barru (62,07\%) (Tabel 3). Populasi ikan beronang asal Lampung menghasilkan variasi genetik yang baik hal ini didukung oleh proporsi polimorfik paling tinggi $(75,86 \%)$. Garcia \& Benzii (1995) mendapatkan polimorfik udang windu berkisar 39\%-77\%, sedangkan udang vaname $80 \%$ (Valerio-Garcia \& GrijalvaChon, 2008) dengan menggunakan penanda RAPD. Polimorfik yang tinggi mengindikasikan bahwa populasi alami jenia ikan tersebut masih besar. Ini menunjukkan bahwa populasi Lampung masih memiliki keragaman genetik yang tinggi. Populasi dengan keragaman genetik yang tinggi mempunyai peluang hidup yang tinggi karena disinyalir mempunyai kemampuan yang lebih baik untuk beradaptasi dengan lingkungannya. Hal yang sama dikemukakan oleh Parenrengi (2001) bahwa polimorfik yang tinggi pada ikan kerapu mengindikasikan rendahnya inbreeding antar populasi. Sementara, pada populasi ikan beronang dari perairan Barru yang memiliki polimorfik terendah menunjukkan penurunan dalam populasi efektif di alam akibat terjadinya inbreeding. Keragaman genetik yang rendah akan mempengaruhi kemampuan spesies untuk dapat memberikan respons terhadap perubahan lingkungan baik buatan maupun alami (Soewardi, 2007). Selanjutnya diuraikan ada tiga hal yang dapat mengancam keragaman hayati pada tingkat gen yaitu (1) kepunahan dari populasi atau spesies, (2) hibridisasi yang dapat menyebabkan terjadinya kombinasi gen-gen yang berasal dari spesies yang berbeda, dan (3) penurunan keragaman genetik intra populasi.

Hasil pengamatan menunjukkan bahwa indeks similaritas tertinggi sebesar 0,9583 diperoleh pada ikan beronang antara populasi Barru dan Sorong, menyusul Barru dan Lampung $(0,8024)$, dan terendah antara Sorong dan Lampung yaitu 0,7996 (Tabel 4). Hal ini memperlihatkan bahwa hubungan kekerabatan antara populasi Barru dan Sorong dekat dan Sorong dan Lampung adalah relatif jauh. Nilai indeks similaritas ikan beronang populasi Barru dan Sorong pada penelitian ini hampir sama nilai indeks similaritas ikan Rutilus rutilus caspicus populasi Gorgan Bay dan Anzali Wetland, Caspian Sea Iran sebesar 0,96 (Keyvansshokooh \& Kalbassi, 2006), dan ikan Channa punctatus yakni 0,9231 (Nagarajan et al., 2006) serta populasi catfish 0,51-0,9 (Kim, 1998). Selanjutnya indeks similaritas ikan Cyprinus carpio antara populasi Indonesia dan India adalah 0,8677 (Basavaraju et al., 2007). Hasil analisis indeks similaritas ikan beronang antara populasi Sorong dan Lampung relatif sama dengan indeks similaritas ikan beronang populasi Teluk Bone dan Selat Makassar, Lante (2010). Parenrengi et al. (2006) menyatakan bahwa indeks similaritas merupakan suatu

Tabel 4. Indeks similaritas antara populasi ikan beronang, S. guttatus

Table 4. Matrix of similarity index among population of rabbitfish, $\boldsymbol{S}$. guttatus

\begin{tabular}{lccc}
\hline $\begin{array}{c}\text { Populasi } \\
\text { Populations }\end{array}$ & Sorong & Barru & Lampung \\
\hline Sorong & - & & \\
Barru & 0.9583 & - & - \\
Lampung & 0.7996 & 0.8024 & - \\
\hline
\end{tabular}


proporsi kesamaan profil DNA organisme intra atau inter populasi. Selanjutnya Rogers (1972) menyatakan semakin tinggi indeks similaritas mencerminkan semakin dekat hubungan kekerabatannya.

Hasil analisis jarak genetik ikan beronang populasi Barru, Lampung, dan Sorong disajikan pada Tabel 5. Jarak genetik antara populasi Barru dan Sorong adalah 0,0426 lebih dekat dibandingkan dengan populasi Barru dan Lampung $(0,2202)$, dan jarak genetik paling jauh adalah Lampung dan Sorong $(0,2237)$. Pada ikan lain mempunyai jarak genetik yang berbeda-beda, antara lain: ikan Rutilus rutilus caspicus populasi Caspian Sea Iran memiliki jarak genetik 0,04 (Keyvanshokooh \& Kalbassi, 2006), ikan kerapu bebek domestikasi memiliki jarak genetik 0,85 (Wahidah, 2004); ikan terbang (Cypselurus opisthopus) populasi Teluk Mandar dan Teluk Tomini memiliki jarak genetik 0,003 (Fahri, 2001); dan ikan kerapu, Epinephelus spp. memiliki jarak genetik
0,20-0,41 (Parenrengi, 2001). Selanjutnya Parenrengi (2001) menyatakan bahwa jarak genetik yang rendah menunjukkan terjadi aliran gen antar populasi. Demikian pula semakin kecil jarak genetik antar individu dalam suatu populasi, maka semakin seragam populasi tersebut (Pandin, 2000).

Jarak genetik ikan beronang yang diperoleh antar lokasi perairan berbeda pada penelitian ini disajikan pada Gambar 3. Dendogram yang dibentuk berdasarkan jarak genetik memperlihatkan bahwa populasi Barru dan Sorong berada dalam satu kelompok karena keduanya memiliki jarak genetik yang paling dekat, sedangkan populasi Lampung dan Sorong mempunyai jarak genetik yang terjauh $(0,2237)$. Hal ini memperlihatkan bahwa ikan beronang populasi Lampung memiliki keragaman genetik masih tinggi. Keragaman genetik tinggi mengindikasikan ketersediaan stok di alam masih relatif tinggi dan penangkapan ikan beronang di perairan

Tabel 5. Jarak genetik antara tiga populasi ikan beronang, S. guttatus

Table 5. Genetic distance of RAPD markers in three populations of rabbitfish, S. guttatus

\begin{tabular}{lccc}
\hline $\begin{array}{c}\text { Populasi } \\
\text { Populations }\end{array}$ & Sorong & Barru & Lampung \\
\hline Sorong & - & 0.0426 & 0.2237 \\
Barru & & - & 0.2202 \\
Lampung & & & - \\
\hline
\end{tabular}
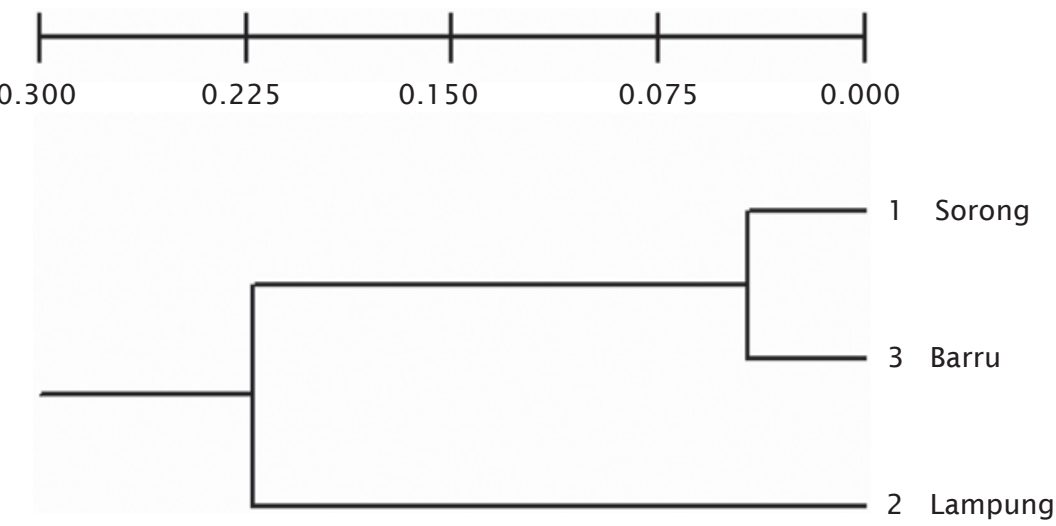

Gambar 3. Dendrogram hubungan kekerabatan tiga populasi ikan beronang (S. guttatus) asal perairan Barru, Lampung, dan Sorong

Figure 3. Dendrogram of genetic distance between three population of rabbitfish, S. guttatus from Barru, Lampung, and Sorong waters 
tersebut masih tergolong selektif, sehingga perkawinan secara acak berjalan dengan baik dan kemungkinan belum terjadi aliran genetik dari kedua lokasi perairan.

Beberapa penelitian menunjukkan bahwa keragaman genetik ikan berhubungan erat dengan kondisi geografis. Nagarajan et al. (2006) menyatakan bahwa keragaman genetik ikan Channa punctatus berhubungan erat dengan kondisi geografis ikan atau berkorelasi positif dengan jarak secara geografis. Letak geografis yang relatif dekat hal ini memungkinkan struktur genetik ikan beronang memiliki kemiripan dan berada dalam satu kelompok. Berdasarkan hasil dendrogram ikan beronang pada penelitian ini menunjukkan dua kelompok populasi yaitu (1) populasi ikan beronang Barru dan Sorong dan (2) populasi ikan beronang Lampung. Jarak genetik ikan beronang populasi Lampung sangat jauh dari populasi Sorong. Hal ini disebabkan oleh daratan Pulau Sulawesi dan Pulau Jawa, sehingga relatif tidak terjadi penghayutan aliran gen ikan beronang dari Sorong. Adanya perbedaan genetik menjadi 2 kelompok pada penelitian ini kemungkinan disebabkan larva ikan secara aktif tetap berada pada habitat di sekitar tempat pemijahannya atau adanya aliran arus dengan variabilitas yang tinggi secara positif larva ikan terbawa menuju habitat perairan lain. Gardner et al. (1991) menyatakan bahwa ada dua faktor yang mempengaruhi keragaman genetik yaitu faktor yang meningkatkan keragaman genetik yaitu mutasi dan migrasi, sedangkan faktor yang menurunkan keragaman genetik adalah seleksi alam dan penghanyutan genetik.

\section{KESIMPULAN DAN SARAN}

Ikan beronang populasi Lampung memberikan polimorfik tertinggi yaitu $75,86 \%$; sementara populasi Sorong sebesar $70,69 \%$; dan terendah dari perairan Barru $(62,07 \%)$. Indeks similaritas ikan beronang tertinggi diperoleh pada populasi Barru dan Sorong yaitu 0,9583 dan terendah antara Barru dan Lampung $(0,7996)$.

Secara geografis populasi ikan beronang dari ketiga perairan dapat dikelompokkan dalam dua kelompok yaitu (1) Barru dan Sorong, dan (2) Lampung. Untuk pengembangan perbenihan ikan beronang di Indonesia, maka disarankan untuk menggunakan ikan yang memiliki keragaman genetik yang tinggi dari perairan Lampung atau perkawinan silang antara populasi Lampung (Sumatera) dengan populasi ikan beronang perairan Barru (Sulawesi Selatan).

\section{UCAPAN TERIMA KASIH}

Penelitian ini dibiaya oleh DIPA Kegiatan Penelitian Pakan, Pembesaran, dan Pembenihan Finfish, Balai Penelitian dan Pengembangan Budidaya Air Payau tahun anggaran 2010. Penulis mengucapkan terima kasih kepada (1) staf peneliti dan teknisi nutrisi yang telah membantu kegiatan penelitian ini, (2) kepada Dr. Andi Parenrengi, M.Sc. selaku penanggung jawab Laboratorium Bioteknologi yang telah memberikan masukan selama penelitian.

\section{DAFTAR ACUAN}

Anonim. 2008. Laporan Statistik Tahunan Dinas Kelautan dan Perikanan Provinsi Sulawesi Selatan, $85 \mathrm{hlm}$.

Arifin, O.Z., Gustiano, R., \& Nugroho, E. 2007. Keragaman genetik populasi ikan nila (Oreochromis niloticus) dalam program seleksi berdasarkan RAPD DNA. Breeding, Genetika dan Bioteknologi Perikanan. Balai Riset Perikanan Budidaya Air Payau, Balai Besar Riset Perikanan Budidaya Laut, Pusat Riset Perikanan Budidaya, hlm. 140-147.

Asma, N.A. 1999. Genetic variation between and within three varieties of domesticated tiger barb (Puntius tetrazona) using RAPD markers. Thesis. Faculty of Medicine and Health Sciences. Universiti Putra Malaysia, $115 \mathrm{pp}$.

Basavaraju. Y., Prasad, D.T., Kumar, K.R.S.P., Naika, U.D., Jahageerdar, S., Srivastava, P., Penman, D.J., \& Mair, G.C. 2007. Genetic diversity in common carp stocks assayed by random-amplified polymorphic DNA markers. Aquaculture Research, 18: 147155.

Fahri, S. 2001. Keragaman genetik ikan terbang (Cypselurus opisthopus) di perairan Teluk Mandar, Teluk Manado dan Teluk Tomini. Tesis. Program Pascasarjana IPB. Bogor, $47 \mathrm{hlm}$.

Ferguson, A., Taggart, T.B., Prodohl, P.A., McMeel, O., Thompson, C., Stone, C., McGinnity, P., \& Hynes, R.A. 1995. The application of moleculer markers to study and conservation of fish population, with special reference to Salmo. J. of Fish Biology, 47: 103-126. 
Garcia, D.K. \& Benzie, A.H. 1995. RAPD markers of potensial in penaeid prawn (Penaeus monodon) breeding programs. Aquaculture, 130: 137-144.

Gardner, E.J., Simmons, M.J., \& Snustad, P.D. 1991. Population and Evolutionary Genetics In Principles of Genetic. Jhon Wiley and Sons Inc., New York, Chichester Brisbane, Toronto, Singapore, p. 566-580.

Keyvanshokooh, S. \& Kalbassi, M.R. 2006. Genetic variation of Rutilus rutilus caspicus (Jakowlew, 1870) populations in Iran based on random amplified polymorphic DNA markers: a preliminary study. Aquaculture Research, 37: 1,437-1,440.

Kim, C.L. 1998. Development of PCR-based DNA markers to identify and characterise Malaysian river catfish, Mystus nemurus (C\&V): RAPD and AFLP. Thesis Master of Science, Faculty of Science and Environmental Studies, Universiti Putra Malaysia, $124 \mathrm{pp}$.

Lamidi, Asmanelli, \& Dalviah. 1996. Pengaruh penambahan vitamin E pada pakan terhadap pertumbuhan dan tingkat kematangan gonad ikan beronang, Siganus canaliculatus, J. Penel. Perik. Indonesia, 2(4): 23-29.

Lante, S., Palinggi, N.N., \& Rachmansyah. 2008. Implantasi Luteinzing Hormone Releasing Hormone-analogue untuk perkembangan dan pemijahan induk beronang (Siganus guttatus). Prosiding Pengembangan Teknologi Perikanan Budidaya. Pusat Riset Perikanan Budidaya, Badan Riset Kelautan dan Perikanan, hlm. 131-137.

Lante, S. 2010. Analisis keragaman genetik populasi ikan beronang (Siganus guttatus) di Selat Makassar dan Teluk Bone. Tesis. Pascasarjana Universitas Hasanuddin, Makassar, $88 \mathrm{hlm}$.

Lante, S. \& Usman. 2010. Pengaruh pemberian pakan buatan dengan kadar lemak berbeda terhadap pertumbuhan dan sintasan ikan beronang (Siganus guttatus). Prosiding Forum Inovasi Teknologi Akuakultur. Pusat Penelitian dan Pengembangan Perikanan Budidaya. Badan Penelitian dan Pengembangan Kelautan dan Perikanan, hlm. 743748.

Lante, S. \& Palinggi, N.N. 2010. Pematangan gonad dan pemijahan induk beronang (Siganus guttatus) dengan rasio jantan dan betina yang berbeda. Prosiding Forum Inovasi Teknologi Akuakultur. Pusat Penelitian dan Pengembangan Perikanan
Budidaya. Badan Penelitian dan Pengembangan Kelautan dan Perikanan, hlm. 205210.

Liu, Z.J. \& Cordes, J.F. 1999. DNA Marker technologies and their applications in aquaculture genetics, Aquaculture, 238: 1-37.

Miller, M.P. 1997. Tools for Population Genetic Analyses (TFPGA). Version 1.3. A windows program for the analysis of allozyme and molecular population genetic data. Department of Biological Science-Box 5640. Northern Arizona University, Fladstaff, Az 86011-5640, 30 pp.

Moria, S.B., Haryanti, Permana, G.N., \& Slamet, B. 2006. Karakteristik Genetik dan Struktur Populasi Ikan Napoleon, Cheilinus undulates di Perairan Indonesia. J. Ris. Akuakultur, 1(3): 315-323.

Nagarajan, M., Haniffa, M.A., Gopalakrishnan, A., Basheer, V.S., \& Muneer, A. 2006. Genetic variability of Channa punctatus populations using randomly amplified polymorphic DNA. Aquaculture Research, 37: 1,1511,155 .

Palinggi, N.N., Lante, S., \& Rachmansyah. 2009. Pemberian vitamin $C$ dalam pakan pembesaran ikan beronang, Siganus guttatus. Prosiding Forum Inovasi Teknologi Akuakultur. Pusat Riset Perikanan Budidaya. Badan Riset Kelautan dan Perikanan, hlm. 931-935.

Pandin, D.S. 2000. Kemiripan genetik populasi kelapa dalam Mapanget Tengah, Bali, Palu dan Sarwana berdasarkan penanda RAPD. Tesis. Program Pascasarjana IPB. Bogor, 45 hlm.

Parenrengi, A. 2001. Studies on genetic variability of groupers (Genus: Epinephelus) from Indo-Malaysian waters using PCRRAPD Analysis. Thesis. Master of Science, Kolej University Terengganu, Universiti Putra Malaysia, 174 pp.

Parenrengi, A., Sulaeman, Suryati, E., \& Tenriulo, A. 2006. Karakteristik genetika rumput laut Kappaphycus alvarezii yang dibudidayakan di Sulawesi Selatan. J. Ris. Akuakultur, 1(1): 1-11.

Rogers, J.S. 1972. Measures of genetic similarity and genetic distance. p. 145-153, In Studies in genetics. VII. (Ed.) Wheeler, M.R. Univ. Texas Publ. 7213, 354 pp.

Soewardi, K. 2007. Pengelolaan Keragaman Genetik Sumberdaya Perikanan dan Kelautan. Departemen Manajemen Sumberdaya Perairan, Fakultas Perikanan 
dan Ilmu Kelautan, Institut Pertanian Bogor, $153 \mathrm{hlm}$.

Valerio-Garcia, R.C. \& Grijalva-Chon, J.M. 2008. Random-amplified polymorphic DNA analysis in hatchery populations and wild pacific white shrimp Penaeus vannamei from the Gulf of California. Aquaculture Research, 39: 666-669.
Wahidah. 2004. Variasi genetik ikan kerapu bebek (Cromileptes altivelis) pada generasi pertama program domestikasi di BBL Lampung dan BBAP Situbondo. Tesis. Institut Pertanian Bogor, $40 \mathrm{hlm}$. 